\title{
ANNOUNCEMENT \\ THE NEW YORK ACADEMY OF SCIENCES \\ Conference on Aging and Cellular Defense Mechanisms
}

\author{
23-27 September, 1991 \\ Modena, Italy
}

\begin{abstract}
The general hypothesis of the conference is that defense mechanisms, such as DNA repair, production of heat shock and other stress proteins, enzymatic and non-enzymatic antioxidant defense systems, poly (ADP-ribose) polymerase activation constitute an integrated network of critical importance for the aging process. Particular emphasis will be given to growth factor deprivation and programmed cell death, and to the nervous and immune systems, in the framework of a molecular biology approach.
\end{abstract}

There will be contributed poster sessions in conjunction with this conference. (Poster sessions are an integral part of the programme.)

For further information contact:

The Marketing Department,

The New York Academy of Sciences,

2 East 63rd Street,

New York, NY 1002.

Tel: 212-838-0230.

Fax: 212-888-2894. 